1. Multan Medical and Dental College, Multan, Pakistan

2. Multan Medical and

Dental College, Multan, Pakistan

3. Nishtar Medical College,

Multan, Pakistan

4. Multan Medical and

Dental College, Multan, Pakistan

5. Multan Medical and

Dental College, Multan, Pakistan

6. Multan Medical and

Dental College, Multan, Pakistan

Corresponding Address:

Muhammad Arslan Iqbal

Multan Medical and

Dental College, Multan, Pakistan.

wiz46221@outlook.com

Article received on: 04/04/2016

Accepted for publication:

10/06/2016

Received after proof reading:

08/08/2016

\title{
SPINA BIFIDA; \\ THE BASIC AND CLINICAL REVIEW \\ wiz46221@outlook.com
}

\begin{abstract}
Muhammad Arslan Iqbal', Muhammad Zohaib Chaudhary ${ }^{2}$, Muhammad Waseem Abbas ${ }^{3}$,
\end{abstract} Faiza Maqsood ${ }^{4}$, Fiza Fatima ${ }^{5}$, Muhammad Nouman Iqbal ${ }^{6}$

ABSTRACT: Spina Bifida (SB) is a neural tube defect (NTD) due defect in neural tube, characterized by incomplete closure of spinal column. Occurrence of SB varies in different countries. In developed countries, it is about 0.4 per 1000 births, in US 0.7 per 1000 births and in Asia 1.9 per 1000 births. SB mostly occurs during first trimester of pregnancy. Variants of SB are Spina bifida Occulata, Spina bifida Cystica [meningocele and myelomeningocele], Spina bifida Manifesta and Spina bifida Aperta. Among these myelomeningocele is the most common type. Causing agents of SB may be genetic, non-genetic or environmental factors. Non-genetic factors involve anti-convulsant drugs, anti-epileptic drugs, maternal obesity, maternal diabetes and poor nutritional status (folate and vitamin B12 deficiency). Environmental factors are pesticides, nitrated compounds and air pollution. Common manifestations are brain malformations (Arnold Chiari II malformation and hydrocephalus), spinal cord abnormalities, latex allergy, breathing problems, urological abnormalities and cardio-metabolic dysfunction. Diagnostic techniques for Spina bifida are ultrasound screening, Magnetic Resonance Imagining (MRI), amniocentesis and maternal serum alpha-fetoprotein. To prevent the risk of Spina bifida, it is recommended for the mother to use $0.4 \mathrm{mg}$ of folic acid per day or in mothers affected with multiple pregnancies recommended dose of folic acid is $4 \mathrm{mg}$ per day.

Key words: $\quad$ Folic acid; myelomeningocele; myeloschisis; neuropore; NTD

Article Citation: Iqbal MA, Chaudhary MZ, Abbas MW, Maqsood F, Fatima F, Iqbal MN. Spina bifida; the basic and clinical review. Professional Med J 2016;23(8):893-901. DOI: $10.17957 / T P M J / 16.3383$

\section{INTRODUCTION}

Spina bifida (SB) is a Latin word which means "split spine". The most commonly occurring complex congenital malformation of CNS is spina bifida and it is associated with lifelong morbidity having a complex etiology involving environmental and genetic factors. ${ }^{1-5}$ First trimester of pregnancy is most vulnerable phase during which spina bifida usually occurs. ${ }^{6}$ The most common type of SB is myelomeningocele. ${ }^{7}$ The most common manifestations of SB are fecal incontinence, hind brain herniation (Arnold Chiari II syndrome) and hyderocephalus associated with orthopedic abnormalities like talipes, hip dislocation etc. ${ }^{8}$ SB varies significantly by country from 0.1 to 5 per 1000 births. On average in developed countries it occurs in about 0.4 per 1000 births, in US 0.7 per 1000 births and in India 1.9 per 1000 births. $^{9-12}$

\section{What is Spina Bifida?}

Spina bifida is neural tube defect which results due to failure of closure of neural tube. ${ }^{13}$ It is characterized by incomplete closure of spinal column. In SB spinal cord, its coverings and vertebral arches develop abnormally during gestation. Spina bifida is a heterogeneous disorder. ${ }^{14}$

\section{Causes of Spina Bifida}

The causes of spina bifida are classified into three factors:

1. Genetic Factors

2. Non-Genetic Factors

3. Environmental Factors

\section{Genetic Factors}

The sequences of the coding regions revealed that patients with neural tube defects (NTDs) have missense mutation (i.e. of amino acid). ${ }^{15}$ Folate one carbon metabolism function is performed by enzymes which are encoded by NTD associated genes. 
In these enzyme groups one enzyme is 5, 10 methylene tetrahydrofolate reductase (MTHFR), an enzyme that produces 5 methyl tetrahydrofolate which converts homocysteine into methionine. The variant MTHFR C677T, produced due to the conversion of valine to alanine at codon 222, has reduced activity of the enzyme. This mutation either in mother or fetus results in neural tube defects when folate level in mother is low. ${ }^{16}$ The mutations in genes of glycine cleavage system also causes neural tube defects. The mutations in glycine cleavage system genes alter the activity of glycine decarboxylase and amino methyl transferase which alters the breakdown of glycine within mitochondria, a step of folate metabolism. ${ }^{13}$

\section{Non-Genetic factors}

The anti-convulsant valproic acid when taken by a pregnant women causes neural tube defects in a fetus. ${ }^{17}$ The action of valproic acid is to inhibit histone decarboxylase, which alters the functioning of proteins leading to neural tube defects. ${ }^{18}$ Periconceptional intake of folic acid reduces NTDs by $70 \%$. Antiepileptic drugs are associated with NTDs. Other factors contributing to NTDs include maternal pyrexia, maternal obesity, maternal diabetes, poor nutritional status, folate and vitamin B12 deficiency. ${ }^{19}$

\section{Environmental factors}

The environmental factors involve following: ${ }^{13}$

- Indoor air pollution

- Organic solvents

- Pesticides

- Polycyclic aromatic hydrocarbons

- Nitrates related compounds

- Air pollution

\section{Epidemiology and Prevalence}

The prevalence of SB vary in the world but on average ranges around $0.1 \%$.There are no recent cases of SB in South Africa but previously it was reported around 0.77-6.1/1000 particularly higher in rural areas. The recurrence of NTDs is greater than $5 \%$ for a women having more than one child affected by NTDs. ${ }^{19,20}$

Following factors contribute in the epidemiology of NTDs:

> Maternal hyperthermia is one of the early factor of pregnancy contributing in NTDs along with maternal caffeine and drug usage during pregnancy. ${ }^{21,22}$

$>$ The families having low socioeconomic status, there is increased risk of NTDs. ${ }^{23}$

$>$ There is increased risk of NTDs in mothers having age less than 19 years and greater than 40 years. ${ }^{24}$

$>$ Occurrence of NTDs is different in different parental races. In USA, recent studies (20032005), in non-Hispanic whites the prevalence for NTDs per 1,000 births was 2.0, in Hispanics was 1.96 and 1.74 for non-Hispanic blacks. ${ }^{25}$

\section{Sign and Symptoms of Spina Bifida}

These include following: ${ }^{14}$

- Children having SB have unrecognized pain which affects their quality of life.

- Anorexia, dysphagia, vomiting, poor feeding.

- Change in bowel or bladder function

- Headache, irritability, lethargy.

- Hoarseness or stridor, aspiration, breathe holding spell.

- Increasing head circumference with bulging anterior fontanelle.

- Sensory loss or weakness in lower extremities, deterioration of gait.

- Change in deep tendon reflexes.

- Esortropia, diplopia, paralysis of upward gaze.

- Rapidly progressive scoliosis.

- Decubitus ulcer.

\section{Classification}

Spina bifida is classified into following types: ${ }^{26}$

1. Spina bifida Occulata

2. Spina bifida Cystica

3. Spina bifida Menifesta

4. Spina bifida Aperta

\section{Spina bifida Occulata}

It occurs with normal meninges and normal elements. There is no protrusion of meninges 
and spinal cord and defect is covered by muscles and skin. It is of no clinical significance because it does not show any symptoms. Rarely tuft of hairs are present at defective site. In about few percent $0.8 \%$ in 6000 cases low back pain is present. ${ }^{27,28}$

\section{Spina bifida Cystica}

In this type a cystic swelling is present at the site of lesion. The cystic swelling may contain meninges or both meninges and spinal cord. Spina bifida cystica has two sub-variants: ${ }^{28}$

- Spina bifida cystica with meningocele

- Spina bifida cystica with myelomeningocele

\section{Spina bifida Menifesta}

This type of spina bifida presents with surface manifestations such as hemangioma, hair, sinus tract, and covered or open neural elements. ${ }^{27}$

\section{Spina bifida Aperta}

In this type of spina bifida there is a complete aperture and there is an absence of skin at the defective site and neural tissue is exposed. It is always associated with myeloschisis. The site of spina bifida aperta is usually covered by reddish, semi-transparent, oozing membrane that merges into surrounding skin. ${ }^{28}$

\section{Myelomeningocele}

Failure of closure of neural tube or secondary reopening of the closed neural tube is called myelomeningocele. ${ }^{29}$ Vertebral levels of myelomeningocele are given in Table-1(a). ${ }^{30,31}$

\begin{tabular}{|c|c|c|}
\hline Classification & $\begin{array}{l}\text { Levels of } \\
\text { vertebrae }\end{array}$ & Signs \& Symptoms \\
\hline First Category & $\begin{array}{l}\text { Higher Thoracic } \\
\text { and Lumber }\end{array}$ & Lack of quadriceps \\
\hline $\begin{array}{l}\text { Second } \\
\text { Category }\end{array}$ & Lumber (L3\&L4) & $\begin{array}{l}\text { Lack of gluteus } \\
\text { maximus \& } \\
\text { gluteus medius } \\
\text { Tendenlenberg's } \\
\text { sign }\end{array}$ \\
\hline \multirow[b]{2}{*}{ Third Category } & $\begin{array}{c}\text { Higher Sacral } \\
\text { Level }\end{array}$ & $\begin{array}{l}\text { Weakness in Ankle } \\
\text { Planter flexors }\end{array}$ \\
\hline & $\begin{array}{l}\text { Lower Sacral } \\
\text { Level }\end{array}$ & $\begin{array}{c}\text { Weakness in } \\
\text { intrinsic muscles of } \\
\text { foot }\end{array}$ \\
\hline
\end{tabular}

Table-I (a). Vertebral levels of myelomeningocele

\section{Pathoembryology}

There are two distinct phases of neural tube formation primary and secondary. Primary neurulation starts on day 22 post-fertilization. Cranial neuropore closes on day 24 and caudal neuropore closes on day 26 . Neural tube defects result from failure of any neurulation sequence and there are typically open defects. The most severe spinal defect is craniorachischisis. If the cranial neurulation fails then result is anencephaly. ${ }^{32}$

\section{Consequences}

The most commonly occurring consequences are: ${ }^{13,14}$

- Brain Malformations

- Chiari II malformation

- Hydrocephalus

- Spinal cord abnormalities

- Latex allergy

- Breathing problems

- Pressure ulcer

- Urologic abnormalities

- Cardio-metabolic dysfunction

Brain malformations

Abnormalities of brain include Chiari type Il syndrome, agenesis of corpus callosum, hypoplasia of cranial nuclei, diffused micro structural anomalies. The common manifestations of such defects are learning disabilities including non-verbal learning disorders, attention deficit hyperactivity disorder and strabismus. ${ }^{14}$

\section{Chiari II malformation}

In this malformation the posterior fossa is small and brainstem is displaced to the cervical canal. This leads to compression of brainstem which may be caused by abnormal development of ventricle. Respiratory and swallowing difficulties are associated with this malformation. ${ }^{33}$ In brain defects the Chiari II malformation occurs in almost $90 \%$ cases. ${ }^{34}$ The signs and symptoms of Chiari II malformation are given in Table-l(b).

\footnotetext{
Dysphagia, poor or prolonged, feeding, cyanosis Hoarseness of voice, coughing and nasal regurgitation Aspiration with or without pneumonitis

Apnea, including disordered breathing during sleep Breath holding spells

Opisthotonos
}

Table-I (b). Signs and Symptoms of Chiari II Malformation 


\section{Hydrocephalus}

It is a diverse group of conditions resulting from impaired circulation and absorption of cerebrospinal fluid. ${ }^{35,36}$ Hydrocephalus stretches the white matter mainly corpus callosum. Hydrocephalus is associated with motor and cognitiveabnormalities. ${ }^{37-40} \mathrm{Hydrocephalusoccurs}$ in about $85 \%$ patients with myelomeningocele. ${ }^{41,42}$

\section{Spinal cord abnormalities}

Spinal cord abnormalities include both loss of sensory and motor function. Loss of sensory sensation leads to ulcers and loss of motor function leads to musculoskeletal abnormalities. ${ }^{14}$ The spinal cord fixation is referred to as tethered spinal cord resulted from variety of conditions mainly from repaired myelomeningocele. ${ }^{43-46}$ The consequences of spinal cord abnormalities are given in Table-I(c).
- $\quad$ Lower Limb Weakness

- $\quad$ Back Pain, Pain in legs

- Pes cavus

- Gait impairment

- Atrophy of lower limb muscles

- Sensory loss of lower limb

- Functional changes in bowel and bladder

- Decubitus ulcer formation

- Scoliosis

- Local swelling in the back

Table-I (c). Consequences of spinal cord abnormalities

\section{Latex allergy}

Latex allergy is hypersensitivity to latex due to the presence of igE antibodies. ${ }^{47}$ There is a suggestion of genetic association between spina bifida and latex allergy. ${ }^{48,49}$ More than $50 \%$ of children who have myelomeningocele develop latex allergy. ${ }^{14}$ In cases of spina bifida the percentage of latex allergy is $20-40 \%$. The first case of latex allergy was reported in 1989. ${ }^{50-53}$

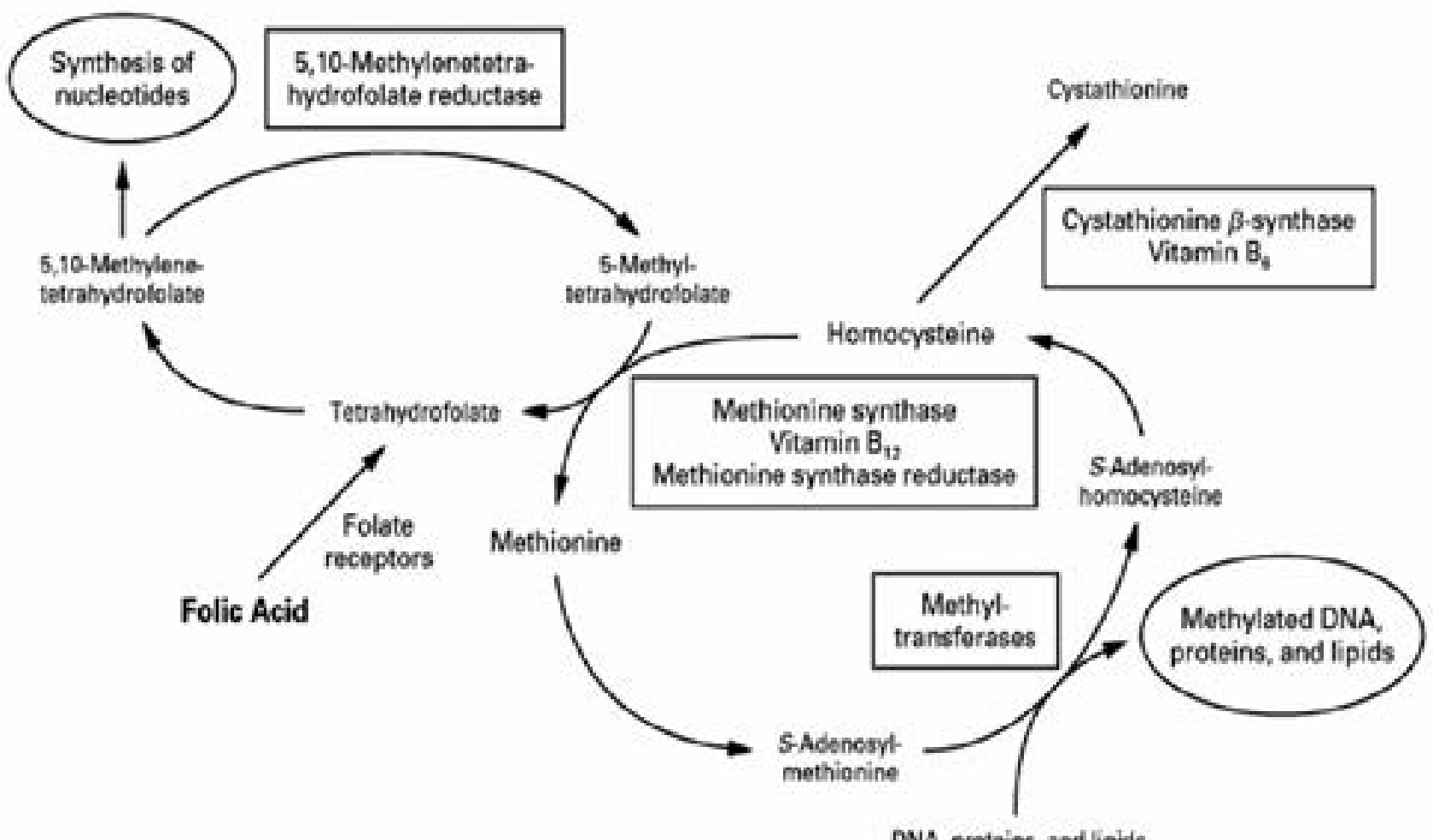

DNA, proteins, and lipids

Figure-1. Role of folic acid 


\section{Breathing problems}

Breathing problems are commonly associated with spina bifida which includes upper airway obstruction, vocal cord palsy, apnea and hypoventilation and severe sleep disordered breathing. These problems may be fatal and can cause death. ${ }^{54-59}$

\section{Pressure Ulcers}

Children with spina bifida are at a great risk of suffering from pressure ulcers. Pressure ulcers require long and complex treatments. Support surfaces, positioning, nutrition and supplements are used for treatment of pressure ulcers. ${ }^{60-63}$

\section{Urologic abnormalities}

Urologic abnormalities associated with spina bifida are vesicouretral reflex (21-25\%), cryptorchidism (10-30\%), bladder exostrophy $(6.8 \%)$, hypospadias $(0.1 \%)$, unilateral renal agenesis (2-8\%), uretropelvic junction obstruction $(1-3 \%)$, multicystic dysplastic kidney $(7-13 \%)$ and horseshoe kidney (2-7\%). ${ }^{64-74}$

\section{Cardio-Metabolic Dysfunction:}

People having SB have increased body mass index (BMI) and percent body fat than that of people without SB. Young adults and children having SB have decreased muscular strength and aerobic fitness in addition to having increased body fat. ${ }^{75-78}$ Persons having SB tend to have decreased physical activity which leads to obesity in these patients and hence causing cardio-metabolic disease. ${ }^{79}$

\section{NTD screening techniques}

NTD screening techniques are of two types:

1. Non-invasive diagnostic methods

2. Invasive diagnostic methods

\section{Non-invasive diagnostic methods \\ Ultrasound screening}

Forthe detection offetal anomalies including NTDs, ultrasonography is the non-invasive screening technique of choice because of its detection sensitivity, safety and cost optimality. According to Society of Obstetricians and Gynecologists of Canada (SOGC), ultrasound should be offered to all pregnant women during the second trimester and it is safer than amniocentesis diagnostically because amniocentesis causes infection or spontaneous abortion. ${ }^{80-82}$ During ultrasound, visible feature in second trimester includes abnormal skull shape (lemon sign), cerebellar abnormalities (banana sign) and abnormality in the lower limb movement. ${ }^{81}$

\section{Fetal MRI (Magnetic Resonance Imagining)}

During 23 and 32 weeks of gestation, for the proper imagining of the subarachnoid space and fetal brain, fetal MRIs are usually performed. MRI provides us good contrast between the soft tissue regardless of maternal obesity, fetal life and oligohydramnios..$^{80,83}$

\section{Maternal serum AFP (alpha fetoprotein)}

Maternal serum alpha fetoprotein (MSAFP) screening is conducted during the second trimester between 15 and 18 weeks of gestation. ${ }^{84}$

\section{Invasive diagnostic methods Amniocentesis}

Amniocentesis is usually performed between the $15^{\text {th }}$ and $20^{\text {th }}$ gestational weeks for the detection of genetic mutations and NTDs. ${ }^{80,84}$

\section{Treatment and management}

The management and treatment of SB involves surgery, ventricoperitoneal shunt, bladder and urinary tract management and fetal surgery with stem cells. The surgery is conducted within 48 hours of birth to close the child back to minimize the spread of infections, otherwise that can result in meningitis. A ventricoperitoneal shunt is needed for the treatment of almost all the neonates with thoracic level lesion, $85 \%$ of lumber level lesion and $70 \%$ of sacral level lesion. ${ }^{13}$ Posterior fossa decompression surgery is conducted in severe cases. ${ }^{85}$ Shortly after birth orthopedic deformities are treated which require long term follow-up. Urinary tract management involves intermittent catheterization, pharmacological drugs and surgery. ${ }^{86}$ Bowel management involves suppositories, laxatives or antegrade colonic or traditional enemas. ${ }^{13,87}$ To monitor fetal heart function intra-operative echocardiography is 
used. Stem cell surgery is done which enhances the neural crest cell differentiation. ${ }^{13,88}$

\section{Prevention}

The mother is administrated with folic acid containing multi-vitamin which reduces the risk of SB. ${ }^{89}$ It is recommended for the mother to take $0.4 \mathrm{mg}$ of folic acid per day or in affected women to take $4 \mathrm{mg}$ per day. ${ }^{90}$

\section{Role of Folic Acid}

The exact mechanism by which folic acid prevents SB remains unclear but some studies show that exogenous folic acid play role in embryonic cell proliferation by enhancing the pyrimidine and purine synthesis. Or through its role in regulation of epigenetic modifications (methylation) of DNA. ${ }^{13,91,92}$ The role of folic acid is explained in Figure- 1.93

\section{Copyright@ 10 June, 2016.}

\section{REFERENCES}

1. Kumar A, Tubbs RS. Spina bifida: A diagnostic dilemma in paleopathology. Clin Anat 2011; 24:19-33.

2. Moldenhauer JS. In utero repair of spina bifida. Am J Perinatol 2014; 31:595-604.

3. Urrutia J, Cuellar J, Zamora T. Spondylolysis and spina bifida occulta in pediatric patients: Prevalence study using computed tomography as a screening method. Eur Spine J 2014.

4. Liptak G, El Samra A. Optimizing health care for children with spina bifida. Dev Disabil Res Rev 2010; 16:66-75.

5. Dennis M, Barnes $M$. The cognitive phenotype of spina bifida myelomeningocele. Dev Disabil Res Rev 2010; 16:31-39.

6. spina bifida: condition information. 2012; Available at: https://en.wikipedia.org/wiki/Spina_bifida\#cite note-Springer-11. Accessed $20^{\text {th }}$ March 2016.

7. Elwood JM, Little J, Elwood JH. Epidemiology and Control of Neural Tube Defects. Monographs in Epidemiology and Biostatistics. Oxford, UK:Oxford University Press; 1992.

8. Oakeshott P., Hunt, GM, Poulton A, Reid F. Open spina bifida: birth findings predict long-term outcome. Arch. Dis. Child 2012; 97:474-476.

9. M. Memet Ö $\square z e k$. Spina bifida: management and out- come. Milan: Springer. p. 2008; 58.

10. Kondo A, Kamihira O, Ozawa H. Neural tube defects: prevalence, etiology and prevention. International journal of urology: official journal of the Japanese Urological Association 2009; 16(1):49-57.

11. How many people are affected by or at risk for spina bifida? 2012; Available at: https://en.wikipedia.org/wiki/ Spina_bifida\#cite_note-Springer-11. Accessed $19^{\text {th }}$ March 2016.

12. Bhide P, Sagoo GS, Moorthie S, Burton H, Kar A. Systematic review of birth prevalence of neural tube defects in India. Birth defects research. Part A, Clinical and molecular teratology 2013; 97(7):437-43.

13. Andrew JC, N.Scott A, Lyn SC, et al. Spina bifida. Nature review's disease primers 2015; 1:1-18.

14. Gregory SL, Nienke PD. Myelomeningocele. Pediatrics in Review 2010; 31; 443-450.

15. Jose MB. Netto, Andre NB, Andre AF, Luis MP. Spinal Dyraphism: A Neurosurgical Review for the Urologist. Reviews in Urology 2009; 11(2):71-81.

16. Franklin J., EJ Ploetner. Painful Spina Bifida Occulta with Review of the Literature. Journal of neurosurgery 1953; 10(1):19-27.

17. Laiq HS. Nervous system. In: human Embryology $.2^{\text {nd }}$ ed. Karachi KH: Paramount publishing enterprise 2011:287-314.

18. Gardner WJ. Myelomeningocele, the result of rupture of the embryonic neural tube. Cleve Clin J Med 1960; 27:88-100.

19. Bauer SB, Labib KB, Dieppa RA, Retik AB. Urodynamic evaluation of boy with myelodysplasia and incontinence. Urology 1977; 10:354-362.

20. Battibugli S, Gryfakis N, Dias L, et al. Functional gait comparison between children with myelomeningocele: shunt versus no shunt. Dev Med Child Neurol 2007; 49:764-769.

21. Müller F, O'Rahilly $R$. The development of the human brain, the closure of the caudal neuropore, and the beginning of secondary neurulation at stage 12 . Anat. Embryol 1987; 176:413-430.

22. McLone DG, Knepper PA. The cause of Chiari II malformation: a unified theory. Pediatr Neurosci 1989;15:1-12.

23. Barkovich AJ, Raybaud C. Pediatric Neuroimaging. Lippincott Williams \& Wilkins, 2011. 
24. Drake JM, Kestle JR, Milner R, et al. Randomized trial of cerebrospinal fluid shunt valve design in pediatric hydrocephalus. Neurosurgery 1998; 43:294-303.

25. Kestle JR, Drake JM, Cochrane DD, et al. Lack of benefit of endoscopic ventriculoperitoneal shunt insertion: a multicenter randomized trial. J Neurosurg 2003; 98:284-290.

26. Del Bigio, MR. Neuropathology and structural changes in hydrocephalus. Dev. Disabil. Res. Rev. 2010; 16, 16-22.

27. Hampton LE, et al. Hydrocephalus status in spina bifida: an evaluation of variations in neuropsychological outcomes. J. Neurosurg. Pediatr. 2011; 8,289-298.

28. Treble A, Juranek J, Stuebing KK, Dennis M, Fletcher JM. Functional significance of atypical cortical organization in spina bifida myelomeningocele: relations of cortical thickness and gyrification with IQ and fine motor dexterity. Cereb. Cortex 2013; 23:2357-2369.

29. Hannay HJ. et al. Auditory interhemispheric transfer in relation to patterns of partial agenesis and hypoplasia of the corpus callosum in spina bifida meningomyelocele. J. Int. Neuropsychol. Soc. 2008; 14:771781.

30. McLone DG, Czyzewski D, Raimondi AJ, Sommers RC. Central nervous system infections as a limiting factor in the intelligence of children born with myelomeningocele. Pediatrics. 1982; 70:338-342.

31. Johnston MV, Kinsman S. Congenital anomalies of the central nervous system. In: Behrman RE,Kliegman RM, Jenson HB, eds. Nelson Textbook of Pediatrics. 17th ed. Philadelphia: W.B. Saunders; 2004; 1989-1992.

32. Barson AJ. The vertebral level of termination of spinal cord during normal and abnormal development. J Anat. 1970; 106:489-497.

33. Pérez LM, Barnes N, MacDiarmid SA, et al. Urological dysfunction in patients with diastematomyelia. $J$ Urol. 1993; 149:1053-1055.

34. Streeter GL. Factors involved in the formation of the filum terminale. Am J Anat. 1919; 25:1-11.

35. Wilson DA, Prince JR. MR imaging determination of the location of the normal conus medullaris throughout childhood. AJR Am J Roentgenol. 1989; 152:10291032.

36. Yassin MS, Sanyurah S, Lierl MB, et al. Evaluation of latex allergy in patients with meningomyelocele. Ann Allergy 1992; 69:207-211.
37. Szepfalusi Z, Seidl R, Bernert G, et al. Latex sensitization in spina bifida appears disease-associated. J Pediatr. 1999; 134:344-348.

38. Nunez R, Rico A, Lopez R, et al. Sensitization to the latex in injured medullary. Allergy. 1997; 52:68.

39. Slater JE. Rubber anaphylaxis. N Engl J Med. 1989; 17:1126-1130.

40. Beezhold DH, Sussman GL, Liss GM, Chang NS. Latex allergy can induce clinical reactions to specific foods. Clin Exp Allergy. 1996; 26:416-422.

41. Tosi LL, Slater JE, Shaer C, Mostello LA. Latex allergy in spina bifida patients: prevalence and surgical implications. J Pediatr Orthop. 1993; 13:709-712.

42. Charous BL. The puzzle of latex allergy: some answers, still more questions. Ann Allergy. 1994; 73:277281.

43. Ward SL, Nickerson BG, van der HA, et al. Absent hypoxic and hypercapneic arousal responses in children with myelomeningocele and apnea. Pediatrics 1986; 78:44-50.

44. Gozal D, Arens R, Omlin KJ, et al. Peripheral chemoreceptor function in children with myelomeningocele and Arnold-Chiari malformation type 2. Chest. 1995; 108:425-431.

45. Kirk VG, Morielli A, Gozal D, et al. Treatment of sleep disordered breathing in children with myelomeningocele. Pediatr Pulmonol 2000; 30:445-452.

46. Kirk VG, Morielli A, Brouillette RT. Sleepdisordered breathing in patients with myelomeningocele: the missed diagnosis. Dev Med Child Neurol 1999; 41:4043.

47. Waters KA, Forbes $P$, Morielli A, et al. Sleep-disordered breathing in children with myelomeningocele. J Pediatr 1998; 132:672-681.

48. Stevenson KL. Chiari type II malformation: past, present, and future. Neurosurg Focus 2004; 16(5):1-7.

49. Okamoto GA, Lamers JV, Shurtleff DB. Skin breakdown in patients with myelomeningocele. Arch Phys Med Rehabil 1983; 64:20-23.

50. Harris MB, Banta JV. Cost of skin care in the myelomeningocele population. J Pediatr Orthop 1990; 10:355361 .

51. Whitney J, Phillips L, Aslam R, et al. Guidelines for the treatment of pressure ulcers. Wound Repair Regen 
2006; 14:663-679.

52. Stechmiller JK, Cowan L, Whitney JD, et al. Guidelines for the prevention of pressure ulcers. Wound Repair Regen 2008; 16:151-168.

53. Netto JMB, Perez LM, Joseph DB. Is proactive clean intermittent catheterization safe and practical in newborns with spinal dysraphism? Pediatrics. 1999; 104:851.

54. Doroshow LW, Abeshouse BS. Congenital unilateral solitary kidney: report of 37 cases and are view of the literature. Urol Surv. 1961; 11:219-229.

55. Campbell MF. Anomalies of the kidney. In: Campbell MF, Harrison JH, eds. Urology. Vol. 2. 3rd ed. Philadelphia: W.B. Saunders; 1970:1416-1486.

56. Ransley PG. Vesicoureteric reflux: continuing surgical dilemma. Urology. 1978; 12:246-255.

57. Epidemiology of bladder exstrophy and epispadias: a communication from the International Clearinghouse for Birth Defects Monitoring Systems. Teratology. 1987; 36:221-227.

58. Hutson JM, Beasley SW, Bryan AD. Cryptorchidism in spina bifida and spinal cord transection: a clue to the mechanism of transinguinaldescent of the testis. J Pediatric Surg. 1988; 23:275-277.

59. Berkowitz GS, Lapinski RH, Dolgin SE, et al. Prevalence and natural history of cryptorchidism. Pediatrics. 1993; 92:44-49.

60. Liebeschuetz S, Thomas R. Unilateral multicystic dysplastic kidney. Arch Dis Child. 1997; 77:368.

61. Sargent MA. What is the normal prevalence of vesicoureteral reflux? Pediatr Radiol. 2000; 9:587-593.

62 Nelson CP, Dunn RL, Wei JT. Contemporary epidemiology of bladder exstrophy in the United States. J Urol. 2005; 173:1728-1731.

63. Shukla AR, Patel RP, Canning DA. Hypospadias. Urol Clin North Am. 2004; 31:445-460.

64. LM Widman, RT Abresch, DM Styne, CM McDonald. Aerobic fitness and upper extremity strength in patients aged 11 to 21 years with spinal cord dysfunction as compared to ideal weight and overweight controls. Journal of Spinal Cord Medicine 2007; 30(1):88-96.

65. MAGC Schoenmakers, JF de Groot, JW Gorter, JLM Hillaert, PJM Helders, T Takken. Muscle strength, aerobic capacity and physical activity in independent ambulating children with lumbosacral spina bifida. Disabil- ity and Rehabilitation 2009; 31(4):259-266.

66. K. Shepherd, D. Roberts, S. Golding, BJ Thomas, RW Shepherd. Body composition in myelomeningocele. American Journal of Clinical Nutrition 1991; 53(1):1-6.

67. LM Buffart, RJG van den Berg-Emons, MS van Wijlen-Hempel, HJ Stam, ME Roebroeck. Healthrelated physical fitness of adolescents and young adults with myelomeningocele. European Journal of Applied Physiology 2008; 103(2):181-188.

68. JH Rimmer, W. Schiller, Chen. Effects of disability-associated low energy expenditure deconditioning syndrome. Exercise and Sport Sciences Reviews 2012; 40(1):22-29.

69. R Douglas Wilson. Prenatal Screening, Diagnosis, and Pregnancy Management of Fetal Neural Tube Defects. J obstet Gynaecol Can 2014; 36(10):927-939.

70. Cargill Y, Morin L; Society of Obstetricians and Gynaecologists of Canada. Diagnostic Imaging Committee. Content of a complete routine second trimester obstetrical ultrasound examination and report. SOGC Clinical Practice Guidelines, No. 223 J Obstet Gynaecol Can 2009; 31:272-5.

71. Taplin SH, Thompson RS, Conrad DA. Cost-justification analysis of prenatal maternal serum alpha-feto proteinscreening. Med care 1998; 32:863-80.

72. Ljubic A, Cetkovic A, Mikic AN, Stamenkovic JD, Jovanovic I, Opincal TS, et al. Ultrasound vs MRI in diagnosis of fetal and maternal complications. Ultrasound Review 2001; 5(2/3):231-42.

73. Chodirker BN, Cadrin C, Davies GAL, Summers AM, Wilson RD, Winsor EJT, et al. Canadian guidelines for prenatal diagnosis. Part 1: genetic indicators for prenatal diagnosis. SOGC Clinical Practice Guidelines, No. 105. J Obstet Gynaecol Can 2001; 23:525-31.

74. McComb JG. Spinal and cranial neural tube defects. Semin. Pediatr. Neurol 1997; 4:156-166.

75. Bauer SB. The management of the myelodysplastic child: a paradigm shift. BJU Int 2003; 92(Suppl. 1):2328.

76. Perez M, Lemelle JL, Barthelme H, Marquand D, Schmitt, $M$. Bowel management with antegrade colonic enema using a Malone or a Monti conduit - clinical results. Eur. J. Pediatr. Surg. 2001; 11:315-318.

77. Saadai, P. et al. Human induced pluripotent stem cell-derived neural crest stem cells integrate into the injured spinal cord in the fetal lamb model of myelomeningocele. J. Pediatr. Surg. 2013; 48:158-163. 
78. Juriloff, DM, Harris MJ. A consideration of the evidence that genetic defects in planar cell polarity contribute to the etiology of human neural tube defects. Birth Defects Res. A Clin. Mol. Teratol 2012; 94:824-840.

79. Amorim MR, Lima, MA, Castilla EE, Orioli IM. Non-Latin European descent could be a requirement for association of NTDs and MTHFR variant $677 \mathrm{C}>\mathrm{T}$ : a meta-analysis. Am. J. Med. Genet. A 2007; 143A:17261732.

80. Robert E, Guidbaud P. Maternal valproic acid and congenital neural tube defects. Lancet 1982; 320:937.

81. Phiel CJ, et al. Histone deacetylase is a direct target of valproic acid, a potent anticonvulsant, mood stabilizer, and teratogen. J. Biol. Chem. 2001; 276:3673436741.

82. K Fieggen, $C$ Stewart. Aetiology and antenatal dioagnosis of Spina Bifida. A Afr Med J 2014; 104(3):218221.

83. Teckie G, Krause A, Kromberg JG. Neural tube defects in Gauteng, South Africa: Recurrence risks and associated factors. S Afr Med J 2013; 103(12):973-977.

84. Moretti ME, Bar-Oz B, Fried S, et al. Maternal hyperthermia and the risk for neural tube defects in offspring: systematic review and meta-analysis. Epidemiology 2005; 16:216-219.

85. Schmidt RJ, Romitti PA, Burns TL, et al. Maternal caffeine consumption and risk of neural tube defects.
Brith Defects Res A Clin Mol Teratol 2009; 85:879-889.

86. Kit Sing Au, Allison Ashley-Koch, Hope Northrup, Epidemiologic and genetic aspects of spina bifida and other neural tube defects. Dev Disabil Res Rev. 2010; 16(1):6-15.

87. Vieira AR, Taucher SC. Maternal age and neural tube defects: evidence for a greater effect in spina bifida than in anencephaly. Rev Med Chil 2005; 133:62-70.

88. Boulet SL, Gambrell D, Shin M, et al. Racial/ethnic differences in the birth prevalence of spina bifida-United States, 1995-2005. MMWR 2009; 57:1409-1413. JAMA 301:2203-2204.

89. Greene ND, Stanier P, Moore GE. The emerging role of epigenetic mechanisms in the aetiology of neural tube defects. Epigenetics 2011; 6:875-883.

90. Wilde JJ, Petersen JR, Niswander L. Genetic, epigenetic, and environmental contributions to neural tube closure. Annu. Rev. Genet. 2014; 48: 583-611.

91. Smithells RW, et al. Apparent prevention of neural tube defects by periconceptional vitamin supplementation. Arch. Dis. Child 1981; 56:911-918.

92. Obican SG, Finnell RH, Mills JL, Shaw GM, Scialli AR. Folic acid in early pregnancy: a public health success story. FASEB J. 2010; 24:4167-4174.

93. Humpath.com - Human pathology. Pathology by systems. Available at: http://www.humpath.com/IMG/ jpg_folate_metabolic_role_nejm_12.jpg. Accessed $15^{\text {th }}$ March $20 \overline{16}$.

\section{AUTHORSHIP AND CONTRIBUTION DECLARATION}

\begin{tabular}{|c|c|c|c|}
\hline Sr. \# & Author-s Full Name & Contribution to the paper & Author $=\mathbf{s}$ Signature \\
\hline 1 & M. Arslan lqbal & Principal Author & \\
\hline 2 & M. Zohaib Chaudhary & $\begin{array}{l}\text { Co-author and drafting of } \\
\text { article }\end{array}$ & \\
\hline 3 & M. Waseem Abbas & $\begin{array}{l}\text { Co-author and review for } \\
\text { intellectual content }\end{array}$ & \\
\hline 4 & Faiza Maqsood & Co-author & epsed \\
\hline 5 & Fiza Fatima & Co-author & $2=10$. \\
\hline 6 & M. Nouman Iqbal & $\begin{array}{l}\text { Co-author and final } \\
\text { approval of article }\end{array}$ & r. $\mathrm{kCO}$ \\
\hline
\end{tabular}

